\title{
The Silence of Heads
}

Richard S. Kayne

New York University

\begin{abstract}
On the basis of considerations involving complementizers, sentence-final particles, need, aspect, tense, focus and topic, agreement morphemes, determiners, verbrelated particles and adpositions, I reach the conclusion that many more heads in the sentential projection line (and elsewhere) must be taken to be silent than is usually thought. I then argue that this state of affairs ultimately reflects the fact that every projecting head is silent.
\end{abstract}

\section{Keywords}

complementizer, sentence-final particle, silence, tense, feature

Studies in Chinese Linguistics, Volume 37, Number 1, 2016, 1-37 DOI: 10.1515/scl-2016-0001 (C)2016 by T.T. Ng Chinese Language Research Centre, Institute of Chinese Studies, The Chinese University of Hong Kong 
It is generally agreed that when a lexical item merges with a phrase, the resulting syntactic object $\{\mathrm{H}, \mathrm{XP}\}$ has as its head/label the lexical item $\mathrm{H}$ (rather than any element contained within the phrase XP). ${ }^{1}$

This leaves open the question of what lexical item merges with what phrase. Put another way, what actually heads what (in one derivation or another, in one language or another)? And what are (some of) the principles that determine the answer to this question?

A related question is whether $\mathrm{H}$ is pronounced or silent. In sections 1 through 13 , I will argue that $\mathrm{H}$ is silent more often than is usually thought. In the remaining sections, I consider the possibility that $\mathrm{H}$ in $\{\mathrm{H}, \mathrm{XP}\}$ is invariably silent.

\section{Complementizers}

It is widely thought that, in English and similar languages, an example of $\{\mathrm{H}, \mathrm{XP}\}$ is $\{$ that, $\mathrm{TP}\},{ }^{2}$ in which that is a lexical item that we call a complementizer and in which that heads $\{$ that, TP\}. Yet Kayne (2010a) argued that English relative clause that is not externally merged with $\mathrm{TP}$, but is rather a relative pronoun in essentially the same sense in which English which is a relative pronoun. Both relative that and relative which are DP-internal determiners that have "lost" their associated noun in the course of the derivation, whether by raising or deletion. ${ }^{3}$ They are of course two different kinds of determiners.

If relative that is a relative pronoun, then taking relative that to be a simple head externally merged high in the sentential domain, as it is in the complementizer analysis of relative that ${ }^{4}$ would be a mistake. Rather, relative that must be subject to (wh-)movement from below much as relative which is. Just as which book is moved in the derviation of:

(1) the book which $<$ book $>$ they were reading

so, from this perspective, is that book moved in the derivation of:

(2) the book that $<$ book $>$ they were reading

1 Cf. Chomsky $(2013,43)$.

2 For the purposes of this discussion, it wouldn't matter if we followed Cinque $(1999,106)$ and replaced TP by MoodP here or if, thinking of Rizzi (1997), we replaced TP by, say, FinP.

3 Relative pronouns seem to be absent from strictly prenominal relatives, as noted by Downing (1978, $392-4)$ and Keenan $(1985,149)$ - for principled reasons, if Kayne (1994) is correct in taking relative pronouns to interfere with the leftward movement of the relative IP that is necessary to derive a prenominal relative, at least in languages in which relatives are consistently prenominal. There are languages whose postnominal relatives seem to consistently lack (visible) relative pronouns. From the text perspective, it may be that those languages are, for reasons to be discovered, unable to strand a determiner in relatives in the way that English can strand which or that.

4 Going back to Bresnan (1972). 
In both (1) and (2) < book> indicates that the noun book was moved along with/ pied-piped by which or that (and subsequently either deleted in situ or moved further). Under this hypothesis, relative that is not merged with a sentential phrase; instead it is merged with a nominal phrase, as determiners are in general.

In Kayne (2010a), I further argued that Romance relative clause che/que is also not a complementizer but a relative pronoun, with the difference being (compared with English that and which) that the Romance morpheme che/que is only a subpart of a complex determiner of the was... für type, ${ }^{5}$ with Romance che/ que corresponding specifically to German was (and English what).

For both English that and Romance che/que, the claim in that paper was extended beyond relative clauses. The occurrence of English that and Romance che/que in what we think of as simple sentential complements (whether to verbs, or adjectives, or nouns) was taken to reduce to their occurrence in relatives, insofar as sentential complements are, it was claimed, actually a subtype of relative clause. ${ }^{6}$ Put another way, English that and Romance che/que are determiner-based relative pronouns even when introducing sentential complements; they are never complementizers in the usual sense of the term, that is, they are never externally merged with TP or with any sentential category similar to TP.

This approach to finite-clause complementizers, which takes them to be relative pronouns that are not heads in the sentential hierarchy, may carry over to nonfinite-clause complementizers like English for (which is found introducing both relative clauses and apparently nonrelative sentential complements). For, too, may turn out to be a subpart of a determiner, again of the was ...für type, ${ }^{7}$ and perhaps similarly for French de and for Italian $d i$ (despite their differing in syntactic behavior in certain respects from $\left.f_{0 r}{ }^{8}\right)$.

If $f o r, d e$ and $d i$ do turn out not to be externally merged heads in the CP area (whether via a relative pronoun-type analysis for them or via a more highly articulated analysis of adpositions), we will have reached the conclusion that, at least in the

\footnotetext{
5 Whose split version is found in dialectal English, for example:

i) What did you buy for a car this year?

On was... für in non-English Germanic, see Leu (2008).

6 Cf. in part Rosenbaum's (1967) idea that sentential arguments are accompanied by it. Also cf. Kayne (2008a).

7 Cf. Kayne (2014a, sect. 8; 2014b); also section 9 below.

8 Cf. Kayne (1981a).
} 
languages under consideration, there are no visible $\mathrm{CP}$-area complementizer heads. ${ }^{9}$ (The heads of the $\mathrm{CP}$ area will have turned out to be [largely] silent. ${ }^{10}$ )

\section{Sentence-final particles}

The term "sentence-final particle" has been used for certain morphemes taken to be heads that are externally merged high in the sentential domain, for example, in Cantonese. ${ }^{11}$ (Such sentence-final particles seem typically to have more interpretive content than what we call complementizers.) But rather than discuss Cantonese directly, let me instead jump to sentences in English that might also initially seem to lend themselves to an analysis involving heads that are externally merged high in the sentential domain.

For (colloquial) English, one might think, for example, of a sentence like:

(3) We're on the list, right?

which has an interpretation close to that of a tag question. A possible analysis would have right in (3) analyzed as a "sentence-final particle" in the above sense. Right in (3) would be merged somewhere high in the sentential domain as a head. (The position of the phrase we're on the list that precedes right in (3) might or might not then be due to movement/internal Merge.)

A second possibility, though, would relate (3) more directly to:

(4) We're on the list, isn't that right?

by attributing to (3) a derivation containing, in addition to what is visible/audible, a silent ISN'T THAT (I will use capitals to indicate non-pronunciation.) The silence of ISN'T THAT in (3) might then be licensed as a whole or piecemeal. If (3) contains silent ISN'T THAT, as in:

(5) We're on the list ISN'T THAT right

9 Cf. to some extent Starke (2004) and Jayaseelan (2008). This conclusion should in turn be related to the observation that the elements we call complementizers usually look like something else (determiners or prepositions), a surprising fact if complementizers were really a category of their own. (Though zhe has no non-complementizer-like use in (contemporary) Czech, as Pavel Caha (personal communication) tells me.)

It is to be noted that this observation would not be accounted for with any depth of explanation by merely saying that complementizers usually come about via "grammaticalization"; for relevant discussion, see Kayne (2010a).

Rigau (1984) had argued that the Catalan counterpart si of English if is not a complementizer. (Extended to if, this will require a revision of Kayne's (1991) account of We're not sure whether/*if to leave or not and related facts in Romance, as well as a rethinking of why French si does not license "stylistic inversion" - cf. Kayne and Pollock (2001).)

Ghomeshi (2001) had Persian ke not heading a functional projection. On complementizers that look like the (light) verb, say in one language or another, see Koopman and Sportiche (1989).

10 On apparent focus and topic heads, see section 12 below.

11 See Matthews and Yip (1994, chap. 18) and Tang (2015). 
then right in (3)/(5) is not a sentence-final particle in the usual sense of the term but rather an adjective akin to the adjective correct as in:

(6) Is that correct?

Right in (3)/(5) is then not merged as a high head in the sentential hierarchy; it is a predicate adjective (as in $(4) /(6))$ that is associated in $(3) /(5)$ with a copula that is silent. If (4) involves leftward movement of the phrase we're on the list past isn't that right, ${ }^{12}$ so would (3), whose derivation would then more specifically include the movement of we're on the list past "ISN'T THAT right". The main point is that if (3) is essentially parallel in derivation to (4), then right in (3) is not a sentencefinal particle, that is, it is not a high externally merged head in the way that it might have been thought to be.

A fairly safe conjecture is:

(7) Various elements that might have been taken to be sentence-final particles in various languages actually have the non-sentence-final-particle status that right has in (3)/(4).

The conjecture in (7) is to be interpreted loosely. It states that various other candidates for being sentence-final particles will turn out not to be simple functional heads merged high in the sentential hierarchy ${ }^{13}$ but, instead, will turn out to be subparts of more complex constituents of some kind (that may or may not closely match "isn't that X").

Sentence-final particles have sometimes been noted to occur only in root sentences. ${ }^{14}$

This seems also to be true of (3):

(8) *That we're on the list, right, is the question.

(9) *John would like to know whether (or not) we're on the list, right.

(The second of these is possible if right is associated with the matrix predicate, but not if right is associated with the embedding.) The preceding two examples indicate that the right in question cannot occur within an embedded sentence. The next two examples make the same point for isn't that right:

(10) *That we're on the list, isn't that right, is the question.

\footnotetext{
12 For recent relevant discussion, see Haddican et al. (to appear).

Any analysis of (3) will need to come to grips with facts such as the following. Alongside:

i) We're on the list, isn't that so?

there is no interpretively parallel:

ii) *We're on the list, so?

${ }^{13}$ Cf. Tang (2015).

14 Cf. for example Law (2002) and Lin (2014).
} 
(11) *John would like to know whether (or not) we're on the list, isn't that right.

(Again, the second of these is possible, but only if isn't that right is associated with the matrix part of the sentence.) Consequently, the restriction to root sentences seen in (8)-(9) is compatible with the linking of (3) to (4).

As a second English example of a putative sentence-final particle, consider:

(12) Where do they live, again?

in which again might initially be thought to be a sentence-final particle of the general sort under discussion and to be externally merged high in the sentential domain. But there is an alternative syntactic analysis of (12) that would more transparently capture the interpretation of (12). ${ }^{15}$ This alternative analysis would relate (12) to:

(13) ?Where do they live, tell me again?

by taking (12) to contain silent TELL and silent ME. ${ }^{16}$ If (12) has an analysis as in:

(14) Where do they live TELL ME again

then again in (12) is an adverb associated with silent matrix TELL and is not a sentence-final particle externally merged high in the sentential structure. ${ }^{17}$

Somewhat similarly, we might take the apparent Taiwanese sentence-final particle kong discussed by Simpson and Wu (2002a; 2002b) to interpretively match, as they suggest, English non-particle I'm telling you, ${ }^{18}$ as in:

(15) He's here, I'm telling you.

15 Cf. Ross (1970), Sauerland (2009), and Sauerland and Yatsushiro (2014).

16 As always, there are interesting restrictions on silent elements, from the present perspective. (An analysis that attempted to do without the silent element here, as for example, with late insertion on the semantic side, would have to grapple with all of the same restrictions while losing the advantage of rich interaction with the syntax.) One is seen in:

i) Tell me again where they live vs.

ii) *Again where they live?

which contrasts in turn with:

iii)?Again, where do they live?

A second is illustrated by:

iv) Tell me later where they live

vs.

v) *Where do they live, later?

Relevant here might also be:

vi) Come again?

17 A reviewer points out that this kind of again is not found with yes/no questions:

i) *Are you happy, again?

This might be due to Where do they live, again? being a subtype of echo question. (A sentence-final particle approach to this again would not be of help, as far as I can see.)

18 I am grateful to Audrey Li for discussion of kong. 
which also seems limited to root sentences:

(16) $(*)$ The fact that he's here, I'm telling you, is very important.

More exactly, (16) can be interpreted as:

(17) I'm telling you that the fact that he's here is very important.

but not as:

(18) The fact that I'm telling you that he's here is very important.

In other words, Taiwanese kong may even synchronically correspond to the verbal subpart of I'm telling you, ${ }^{19}$ rather than being externally merged as a "sentencefinal particle".

As a final, partially similar, example, consider Quebec French, as discussed by Vinet (2000), in which one has interrogative sentences like:

(19) Ils dorment-tu? ("they sleep-you" = "are they sleeping?")

with a postverbal $t u$ that looks like the second person familiar singular subject clitic, yet doesn't seem to have any place in the interpretation. One might try to think of this $t u$ as being an interrogative particle externally merged in the CP-area in Rizzi's (1997) sense or a Force operator as Vinet suggests.

An alternative would be to take such Quebec French sentences to have something significant in common with English: ${ }^{20}$

(20) Are they sleeping, do you know?

with $t u$ in (19) now matching the you of (20) and corresponding, in Quebec French, to the subject of a silent matrix verb KNOW. (In (19) there is no inversion of $i l s$ and dorment; in addition, the derivation of (19) would, since -tu can be followed by VP-material, have to involve remnant movement.)

In Quebec French this - $t u$ is limited to yes-no questions (as opposed to wh-questions, as Vinet (p.382) points out). This limitation may, from the present

19 Simpson and Wu take kong to be a grammaticalized complementizer. From the present perspective, kong is a verb whose personal arguments can be silent (cf. in part Ross (1970)) and whose sentential complement can prepose in the notable way they describe. The "grammaticalization" that kong has undergone involves the preceding two properties, rather than a change in category. Cf. Koopman and Sportiche (1989) also the section on complementizers that precedes this one. Relevant, in addition, is Etxepare (2010), whose proposal for a silent nominal, rather than verbal tell/say, will converge toward the text proposal as the latter brings in Hale and Keyser $(1993 ; 2002)$ below.

20 Non-interrogative you know might be appropriate for other, exclamative examples given by Vinet, such as:

i) C'est-tu choquant! (“"it is $t u$ shocking”) 
perspective, now parallel the contrast between: ${ }^{21}$

(21) Did he go there, do you know?

and:

(22) $(*)$ Where did he go, do you know?

with the latter having a different intonation and feeling as if there are two separate sentences.

If, in the preceding set of examples, right, again, kong and tu are not particles externally merged as high heads in the sentential domain, that is, they do not correspond to $\mathrm{H}$ in any $\{\mathrm{H}, \mathrm{XP}\}$ with XP a sentential phrase, then the high sentential heads needed in these examples would again appear to all be silent as in the discussion of complementizers above.

The next question is, how typical are right, again, kong and $t u$ here?22 If we take them to be typical, the safe conjecture in (7) gives way to the following more controversial pair of conjectures:

(23) All pronounced elements that could have been taken to be sentence-final particles in one language or another actually share the non-sentence-finalparticle status that right, again, kong and tu share.

(24) The high sentential heads in question in such examples are all silent, in all languages. To illustrate the point of (24), let us take (12), now with the analysis:

(25) where do they live [ H [ TELL ME again ] ]

Overt again is not a high sentential head, but rather an adverbial modifying silent TELL. The head $\mathrm{H}$ in whose specifier position the phrase where do they live is found (probably as the result of movement) is silent. ${ }^{23}$

\section{Particles of the English up/down/away type}

In addition to complementizers and sentence-final particles, another familiar set of candidates for being pronounced heads in some $\{\mathrm{H}, \mathrm{XP}\}$ that results from external Merge are particles such as up, down, and away in English and other

21 This contrast holds if the matrix verb is know, but not if it is think.

The subject in these - $t u$ sentences is subject to a definiteness requirement (that is also found with Quebec French subject clitic doubling) according to Morin (2009), whose idea that the preverbal subject is a topic is probably compatible with the text proposal.

22 A reviewer asks about cases of (strictly ordered) multiple sentence-final particles. From the present perspective, such cases would have something in common with:

i) They're in Paris, I think, isn't that right?

ii) *They're in Paris, isn't that right, I think(?)

23 Possibly, where do they live is in the Spec of another silent head H' that is higher than $\mathrm{H}$. 
languages, especially from the perspective of den Dikken (1995, sect. 2.2.2), who takes such particles to head a small clause. However, Collins $(2008,28)$ takes these particles to rather be modifiers of a silent PLACE, in the manner of Terzi (2010). (In addition, Collins has locative particles co-occurring with a silent TO or AT, ${ }^{24}$ in which case that silent TO or AT might correspond to the $\mathrm{H}$ in question, rather than the pronounced particle itself corresponding to $\mathrm{H}$.)

A relevant supporting consideration for the view that these particles do not head a small-clause-like phrase that immediately contains the associated object DP (when there is one) is that the particle away is almost certainly decomposable into $a$ - plus way, as suggested by the pair:

(26) Put/Take it away.

(27) Put/Take it aways.

(The latter is non-standard.) This pair recalls:

(28) It's quite a way(s) from here.

in which one can colloquially have (non-plural) ways instead of way, at least in certain cases.

Taking "particle" away(s) to contain the noun way(s) underdetermines the status of $a$, which may be a clitic-like preposition, as in:

(29) They took aboard the supplies.

(30) They set aside some money.

in which the $a$ - of aboard seems very close to the on of:

(31) They took the supplies on board.

and the $a$ - of aside very close to the to of:

(32) They set some money to the side.

From this perspective, neither aboard nor aside nor away is a plausible head; all are in fact phrasal. ${ }^{25}$

Of note is the fact that on board itself can (at least in my English) display particle-like behavior:

24 Cf. Koopman and Szabolcsi (2000, 221).

It would be natural to extend Collins's proposal to apparently non-locative particles, as in:

i) You'd better finish up that paper.

and to take there to be a silent adposition in (i), too. Cf. Lindner (1981) on the common properties of various instances of out; also the further discussion of up below.

25 On the question whether a pronounced adposition could ever be a projecting head, see section 10 below. 
(33) If we were to take on board the supplies right now,... as opposed to:

(34) *If we were to take on(to) the ship the supplies right now,...

thereby supporting the idea that particles are phrasal, insofar as on board is a phrase. ${ }^{26}$ (The contrast here between on board and on(to) the ship suggests that a particle-like phrase may not contain a determiner. ${ }^{27}$ )

As a further consideration, tilting in favor of a phrasal analysis of at least some English particles, consider:

(35) He put on his coat/He put his coat on.

which almost certainly contains a silent pronoun or reflexive as the object of on, with on then not heading any phrase of the sort "on his coat" or "his coat on". ${ }^{28}$

From a partially different direction, we can also note:

(36) He walked along the river.

whose French counterpart:

(37) Il marchait le long du fleuve. ("he walked the long of-the river")

clearly has long as a noun, thereby increasing the plausibility of taking English along to be prepositional $a-+$ nominal (or adjectival) long. ${ }^{29}$ If so, then in the particle examples:

(38) They brought along their friends.

${ }^{26}$ Cf. the clitic-like movement of "preposition + pronoun" in Berber (v. Ouhalla (2005)), as well as:

i) If you want, I'll send on up the sandwiches (right away).

Algeo $(2006,135)$ has away in British English able to be used as on one's way.

27 Cf. Collins (2008).

28 In French, the particle itself is silent, leaving only the French counterpart of put:

i) Il a mis son manteau. ("he has put his coat")

The contrast in English between:

ii) He took off his coat.

and

iii) *?He has off his coat.

which contrasts in turn with:

iv) He has his coat off.

may suggest even more hidden structure in (iv) than in (ii).

A silent pronoun/reflexive associated with on is called for in a similar way in the case of:

v) We helped him on with his coat.

(fully acceptable to me, though rejected by some) as well as in (with off plus silent pronoun/ reflexive):

vi) We helped him off with his coat.

(fully acceptable to me, though less frequently accepted than (v))

${ }^{29}$ Cf. Kayne's (2014a, sect. 9) proposal that English ago is $a-+-g o$, with $a$ - akin to on (and -go to going, with three years ago then akin to going on three years). 
(39) They brought their friends along.

along is almost certainly phrasal too.

The conclusion, then, is that in sentences like:

(40) They put away their books.

there is little likelihood that away corresponds to $\mathrm{H}$ and their books to XP in any instance of $\{\mathrm{H}, \mathrm{XP}\}$, at any point of the derivation. Though particles like $u p$ and down are not visibly built from two morphemes in the way that away, aboard, aside and along arguably are, it is plausible that the same conclusion holds for them, as Collins (2008) had suggested.

\section{Need and other modal-like elements}

Since need in English can have modal-like behavior:

(41) He needn't leave so early.

(42) *He needsn't leave so early.

(43) *He needn't to leave so early.

it would seem reasonable to think that it should correspond to one of the sentential functional heads in the IP area, in the sense of Cinque (1999).

Yet Harves and Kayne (2012) and Kayne (2007a) have argued, respectively, that transitive verbal need cross-linguistically and modal-like need in English are not primitive verbal elements. Rather, sentences with modal-like need or transitive verbal need necessarily contain a silent light verb, in the manner of Hale and Keyser $(1993 ; 2002)$. (The silent light verb in question is more specifically a counterpart of have. $\left.{ }^{30}\right)$ Need itself is a nominal element, not a verbal one.

30 Taking into account Harves and Kayne (2012) on Finnish, Levinson (2011) on Icelandic, and Halpert and Diercks (2013) on various Bantu languages, silent HAVE may not be directly at the heart of the matter. Rather, it may be that all languages that have a transitive verb corresponding to need are languages that either have an accusative case-assigning verb of possession or else an accusative caseassigning preposition of possession, with accusative then more central than HAVE itself.

Antonov and Jacques (2014)'s discussion of Estonian suggests an additional licensing possibility for transitive verbal need, namely if the language in question has a noun "need" that can itself license accusative.

Antonov and Jacques (2014) also bring in data from Quechua, but as they note there is a complication due to the fact that the Quechua verb they translate as "need" actually has "want" as its primary meaning. (Neil Myler (personal communication) says that "need" may well never be an accurate translation of the Quechua verb in question.)

(Translation problems (and some acceptability judgment problems) arise for Antonov and Jacques's discussion of (Moroccan) Arabic, as brought to my attention by Jamal Ouhalla (p.c.), who suggests that a transitive "have" may actually be developing in parallel to a transitive "need" in that language.) 
If modal-like need is necessarily to be understood as involving a silent HAVE in combination with a nominal need, then modal need (and similarly transitive verbal need) cannot itself be a head in the sentential projection line in the sense of Cinque (1999) (though silent HAVE might be such a head), contrary to what one might have thought.

Cattaneo (2009, chap. 5) suggests that all modals should have a derivation a la Harves and Kayne (2012) and Kayne (2007a), that is, akin to what I have just described for English need. All modals would then be nominal elements that occur in combination with a light verb (or verbs). ${ }^{31}$

If this approach to need (and perhaps other modals) is on the right track, then instead of being headed by need, the modal VP (or $v \mathrm{P}$ ) in (41) will be headed by a silent light verb, much as English They laughed, in the Hale and Keyser (1993; 2002) perspective, has laugh as a noun, and a VP/ $\nu$ P headed by a silent light verb, rather than by any pronounced element. Need is thus another example in which an initially plausible analysis may turn out not to be correct.

\section{Aspect}

English progressive sentences like:

(44) They're playing baseball.

were argued by Bolinger (1971) to contain a silent preposition, ${ }^{32}$ in effect:

(45) they are AT playing baseball

with AT a silent counterpart of at. If Bolinger was right/on the right track, then -ing itself in (44) is very unlikely to be an aspectual head, in which case, any aspectual head present in such sentences would itself be silent (assuming that be is also unlikely to count as an aspectual head).

Similarly, consider:

(46) They're in the process of finishing their paper.

(47) They're on the point of resigning in protest.

Although in the process of and on the point of can be taken to express aspectual notions, these notions would seem to be arrived at compositionally (perhaps with some idiosyncrasy), starting from the nouns process and point (which are

31 If Cattaneo is correct, then clitic climbing cannot be restricted to monoclausal environments in quite the sense of Cinque (2004). The extent to which the non-monoclausal approach to clitic climbing of Kayne (1989) is compatible with the proposed syntactic complexity of modals remains to be determined.

$32 \mathrm{Cf}$. the discussion in Collins (2008, note 13), which contains the idea that -ing could be a light noun, forcing raising to Spec, AT, in a way that is orthogonal to the main point of the text. 
obviously not in the sentential projection line in the sense of Cinque (1999)) and the adpositions in and on. If there is a projecting, specifically aspectual head in these examples, it is therefore very likely to be a silent one. ${ }^{33}$ By extension, it may be that there are no pronounced projecting aspectual heads, that is, no pronounced aspectual heads corresponding to $\mathrm{H}$ in $\{\mathrm{H}, \mathrm{XP}\}$, in the sentential projection line, contrary to appearances.

In this vein (cf. also the earlier discussion of English particles), the aspectlike $u p$ of: ${ }^{34}$

(48) You should drink your milk right up.

may be associated with silent elements that make it similar to:

(49) ?You should drink your milk right up to the end of it.

with it taking your milk as antecedent. Putting this another way, (48) is to be thought of as:

(50) you should drink your milk right up TO THE END OF IT

with silent IT having your milk as its antecedent. If (50) is on the right track, then up in (48) is more likely to be part of a PP "up TO THE END OF IT" than it is to be a sentential aspectual head. ${ }^{35}$

\section{Tense}

Partee (1973) called attention to analogies between tenses and pronouns. A variant of Partee's idea would focus, instead, on analogies between tenses and demonstratives, as suggested especially by languages with multiple past or future tenses distinguished by distance from the present, ${ }^{36}$ in analogy (it would seem) to demonstratives being distinguished in terms of (some notion of) distance from the speaker. This arguably demonstrative facet of tense might then be expressed as follows.

What we think of as a tense morpheme is in fact a demonstrative morpheme restricted to co-occurring with a silent noun TIME. A sentence like:

33 Bolinger's approach to English carries over to at least some other languages, to judge by Laka (2006) and Coon (2010). The text discussion is related to a possible point of weakness in the cartography approach, whose category labels, as for example in Cinque (1999), are often too complex to be plausible primitives.

34 Cf. perhaps the Slavic aspectual particles/prefixes discussed by Łazorczyk (2010).

35 A reviewer notes that (i) is not paralleled by (ii):

i) Finish up your milk!

ii) *Finish up to the end of it your milk!

However, I find improvement in:

iii) ?Finish up your milk to the end of it.

36 As in Great Lakes Bantu languages - cf. Nurse and Muzale (1999, 527). For relevant discussion of "remoteness" morphemes, see Rimell (2005). 
(51) They called yesterday.

would at first approximation correspond to:

(52) they call AT -ed TIME yesterday

The $-e d$ is the restricted demonstrative morpheme in question, akin to that (apart from the restriction to TIME), and [AT -ed TIME] in (52) is a PP parallel to at that time. $^{37}$

The plausibility of there being a silent AT in (51)/ (52) is indirectly enhanced by pairs like: ${ }^{38}$

(53) Back at that time, they were all happy.

(54) Back then, they were all happy.

alongside the impossibility of:

(55) *Back at then, they were all happy.

suggesting that (54), too, contains a silent AT.

The plausibility of there being a silent TIME in (51)/(52) is indirectly supported by sentences like: ${ }^{39}$

(56) They'll leave soon.

which almost certainly contains, as a subpart: ${ }^{40}$

(57) AT A soon TIME

This is suggested by the relative acceptability of:

(58) ?They'll leave at the soonest time possible. in which soon co-occurs with overt time.

One might wonder in passing about the contrast between (58) and the unacceptable:

(59) *They'll leave at a soon time.

This contrast is probably to be related to the higher position within DP of superlatives as compared with simple adjectives, also seen in English in the contrast between:

37 In which case there would be redundancy in a sentence like:

i) They called at that time yesterday.

If demonstratives are phrasal, as argued by Leu (2007), -ed must be accompanied by silent elements specific to demonstratives in addition to being accompanied by silent AT and TIME.

38 Cf. Katz and Postal (1964, 134). For a different view, see Larson (1985).

39 Cf. Liao (2015).

40 On other instances of TIME, see Kayne (2003; 2014). 
(60) They're the best of friends.

and

(61) *They're good of friends.

and in Persian, in the fact that only superlative adjectives are prenominal. ${ }^{41}$ In effect, overt time requires soon not to be too close to it, structurally speaking, while silent TIME does not have that requirement.

There is reason to think that this special positional character of superlatives is also seen in English in: ${ }^{42}$

(62) ?Of all the students, John's the one who's written the fewest number of good papers this year.

VS.:

(63) *John's written (a) few number of good papers this year.

Overt number is incompatible with a few that is too close by, much as overt time with respect to soon. The linked unacceptability of (63) and (59) (vs. the linked acceptability of (62) and (58)) may in turn be related to the fact that (52) has no fully overt exact counterpart: ${ }^{43}$

(64) *They call at -ed time yesterday.

(Since there are no superlative demonstratives, we would not expect a counterpart with tense to (62) or (58).)

The analogy between tense and demonstratives leads, then, to the conclusion illustrated in effect in (52), namely that the pronounced tense morpheme -ed, which might be thought of as a clitic/affixal variant of then, is not itself a projecting head in the sentential domain and, therefore, does not correspond to the $\mathrm{H}$ of a sentential $\{\mathrm{H}, \mathrm{XP}\}$ in the way usually thought. ${ }^{44}$ (If (52) is on the right track, then verb movement will turn out to be an instance of phrasal movement, a result that

41 Cf. Ghomeshi (1996, 145).

$42 \mathrm{Cf}$. Kayne (2005a) on the presence of silent NUMBER modified by few in:

i) John's written (a) few good papers this year.

Stephanie Harves (personal communication) tells me that she accepts:

ii) the few number of friends that I have

though not:

iii) *I have a few number of friends

suggesting that at least for some speakers the definite article has a role to play here that is independent of superlative -est. (It is likely that there are also speakers who accept (iii) itself.)

43 In the following:

i) They called at that time yesterday.

there must now be two PPs containing the noun time/TIME, with one perhaps modifying the other.

44 Whether tense morphemes project at all reduces now to the question whether demonstratives project DP-internally, which they cannot, strictly speaking, if they are phrasal. 
would converge with Nilsen (2003) on Scandinavian V-2 and with Jayaseelan (2010) more generally. ${ }^{45}$ )

\section{Adjectives and adverbs}

Cinque's $(1999 ; 2010)$ work on adverbs and adjectives leads to the conclusion, in his terms, that both adverbs and adjectives sit, for the most part, in specifier positions whose corresponding head is silent. ${ }^{46}$

This conclusion converges with one aspect of the preceding sections of this paper; in $\{\mathrm{H}, \mathrm{XP}\}, \mathrm{H}$ is silent in a substantial number of cases.

\section{Determiners}

Leu (2014) argues that most determiners are phrasal, rather than being simple heads. ${ }^{47}$ If they are phrasal, then they themselves clearly cannot project as heads, that is, they do not correspond to $\mathrm{H}$ in any $\{\mathrm{H}, \mathrm{XP}\}$. Leu takes that position for determiners in general (e.g. for every, for which, and for demonstratives), apart from the definite article itself. At the same time, he notes that in some cases the definite article in some languages seems to depend on the presence of another subpart of what we call DP. For example, in Slovenian ${ }^{48}$ there is a prenominal definite article that appears only preceding a prenominal adjective. Leu's interpretation of this (and of comparable facts in Swiss German and in some Scandinavian languages) is in part that this definite article forms a constituent with the prenominal AP and that it does not head the containing DP. If so, then the DPs in question in these languages must have a silent D, as many languages do in a more obvious way (e.g. English bare plurals) ${ }^{49}$

There are instances of a similar phenomenon in (standard) English too: ${ }^{50}$

(65) *John would like a one.

(66) *John would like a one that's blue.

45 Cf. the English that allows sentences like (cf. Johnson (1988)): (i) Should have John said that in public?

(Possibly, have in such examples is really of - cf. Kayne (1997).)

If verb movement is phrasal, then HMC effects will need to be rethought.

46 This conclusion is orthogonal to the question whether adjectives and adverbs reach their specifier positions by external or by internal Merge.

Pereltsvaig (2007) argues that properties of Russian adjectives support the existence of DP in

Russian, despite the absence of overt articles of the English kind.

47 Cf. Charnavel (2011) on French counterparts of the same, that is, le même, and of a common/a single, that is, un même.

48 Cf. Marušič and Zăucer (2006).

49 On silent Ds, cf. Longobardi (1994). A reviewer points out that enclitic determiners (such as in Scandinavian languages) lead to questions similar to those that arose for -ed in the section on tense earlier.

${ }^{50}$ For more detailed discussion, see Kayne (2015a). 
(67) John would like a blue one.

Following Leu's reasoning, the indefinite article in (67) may form a constituent with blue (plus silent elements) that does not contain one:

(68) [ a blue ] one

in which case $a$ in (67) does not head the DP a blue one (whose head must therefore be silent).

A possible generalization from the discussion in this section would be that pronounced the and $a$ never correspond to the head of what we call DP (whatever the exact constituent structure and whatever silent elements might be present). Whether such a generalization is tenable remains to be seen. If it is tenable, then DPs have silent heads to a greater extent than usually thought.

\section{Adpositions I. $D e$ and $O f$}

In nonpolarity contexts, the French preposition de ('of') can appear DP-initially only if followed by a prenominal adjective: ${ }^{51}$

(69) Marie achète de bons livres. ("M buys of good books" = "M buys good books") (70) *Marie achète de livres.

(71) *Marie achète de livres qui sont bons. ("M buys of books that are good.”)

This contrast recalls the preceding discussion of (65)-(67). It suggests, for (69), the constituent structure shown in:

(72) [ de bons ] livres

in which case de in (69) is clearly (especially given antisymmetry) not the head of de bons livres.

More than (69), colloquial French would have, with a definite article following de $($ des $=d e+l e s)$ :

(73) Marie achète des bons livres. ("M buys of-the good books" = "M buys good books.")

(74) Marie achète de la bonne bière. ("M buys of the good beer" = "M buys good beer.")

With the definite article thus added, an adjective is not required:

(75) Marie achète des livres.

(76) Marie achète de la bière.

\footnotetext{
${ }^{51}$ In addition, the adjective must be plural - cf. Pollock (1998).
} 
Despite this, it is, given (72), plausible to take (74) to contain de la bonne as a constituent:

(77) [ de la bonne ] bière

in which case de would again not be the head of the whole phrase, in this case de la bonne bière.

Plausible in turn, given both (72) and (77), is to take French phrases like:

(78) quelqu'un de célèbre ("someone of famous" = "someone famous") to be as in:

(79) quelqu'un [ de célèbre ]

and to simultaneously take de not to be the head of the whole phrase quelqu'un de célèbre, ${ }^{52}$ but rather to be within a relative-clause-like constituent de célèbre (a "reduced relative clause"). From this perspective, de la bonne in (77)/(74) and de bons in (72)/(69) would be prenominal reduced relative clauses of a particular sort. ${ }^{53}$ If so, then in all of (69), (74), and (78), the D head would itself be silent.

The analysis suggested here for (78), in which French $d e$ introduces a reduced relative, cannot be mechanically transposed to English, if only because English disallows (for reasons that remain to be discovered) a word-for-word counterpart of (78), as well as exact counterparts of (69) and (74):

(80) someone (*of) famous

(81) Mary is buying (*of) good books.

(82) Mary is buying (*of the) good beer.

Yet English of does arguably introduce a relative clause in cases like: ${ }^{4}$

(83) You have a funny way of wording your letters.

There are (at least) two specific reasons for thinking that of wording your letters in (83) is a subtype of relative clause. One is that the $o f$-phrase cannot be omitted: ${ }^{55}$

(84) *You have a funny way.

which recalls:

(85) We would prefer the ones *(that are on the table).

52 Contrary to Kayne (1994, sect. 8.1).

53 This is compatible with Cinque's (2010) claim that some prenominal adjectives are reduced relatives, and others not.

54 Cf. Kayne (2008a).

55 It may be that (i) contains a silent of-phrase and/or that the way in (i) is distinct from that of the text example:

(i) You have a funny way about you. 
The second reason is that in:

(86) You have a different way of wording each type of letter, don't you?

it is perfectly natural to interpret each as having scope over a different. Both of these properties of (83) can be understood to follow from a relative clause analysis of the raising type. A funny way and a different way (both accompanied by a silent counterpart of in and possibly without the indefinite article) originate within the embedding:

(87) ...wording your letters IN a funny way

(88) ...wording each type of letter IN a different way

The phrases a funny way and a different way raise to become, derivationally speaking, the head of the relative. The natural scope interpretation of (86) is licensed prior to that raising, in the manner of "reconstruction". The unacceptability of (84) will follow on the assumption that, in (83), a funny way must originate within an embedded sentence, very much as headway must in:

(89) Everybody is admiring the headway * (that we made).

From this perspective, English has finite relatives introduced by that (or sometimes zero) or a wh-phrase; it has infinitival relatives introduced by for or to or a prepositional wh-phrase; and now we see that English has gerundial relatives introduced by of. Gerundial relatives cannot be introduced by an overt wh- phrase of any sort, for example.:

(90) *You have a funny way in which wording your letters.

though this property is almost certainly not specific to these relatives, but is rather shared with embedded interrogatives:

(91) *We've been wondering (about) where going this summer.

reflecting a general property of English gerunds. ${ }^{56}$

In section 1 above, I suggested that that and for in relative clauses (and sentential complements) might each be a relative pronoun, that is, a determiner in the case of that and a subpart of a determiner in the case of for. If (83) and (86) contain relative clauses introduced by of, the question arises as to the possible

\footnotetext{
56 Despite which, there is some evidence that gerunds allow successive cyclic movement - see Kayne (1981b). The unacceptability of the text example without about might be related to:

(i) *We've been wondering the time.

though an analysis based on Case (cf. Pesetsky (1993)) would have to come to grips with examples like:

(ii) John has been wondering if we should leave right away, and we've been wondering the same thing.

as he notes.
} 
relative pronoun status of $o f$ in those sentences. Presumably, of, like for, would correspond to only a subpart of a determiner. ${ }^{57}$ If so, then in (83) and (86) of could clearly not be the $\mathrm{H}$ of $\{\mathrm{H}, \mathrm{XP}\}$, where XP is the gerund phrase. ${ }^{58}$ (The head of of wording your letters in (83) must then be silent, and the same holds for the head of of wording each letter in (86).)

\section{Adpositions II}

In the spirit of Baker (1985; 1988), Halle and Marantz (1993), Kayne (1994, sect. 4.5) Julien (2002), Starke (2009), and Cinque and Rizzi (2010), among others, I have been following the hypothesis according to which the atomic elements of the lexicon, as far as Merge is concerned, are no bigger than single morphemes. (This hypothesis came up most explicitly in the discussion of particles like away in section 3.) Another way to put this is to say that candidates for $H$ in $\{H, X P\}$ must be monomorphemic. If so, then adpositions that are bimorphemic (and for which the term "adposition" is, strictly speaking, misleading) are precluded from corresponding to $\mathrm{H}$ in $\{\mathrm{H}, \mathrm{XP}\}$. One relevant example is seen in English in:

(92) despite that

whose similarity to:

(93) in spite of that

makes it virtually certain that despite contains the morpheme spite and therefore also a morpheme $d e-.{ }^{59}$

A second example is seen in the set:

(94) behind, before, below, between, beyond

which are almost certainly to be analyzed as containing a be- morpheme in addition to hind (cf. hindsight, hindquarters), fore (cf. come to the fore), low, -tween (cf. twin) and -yond (cf. yonder). A third is:

57 The whole determiner might be what in the way of, thinking in part of German was für and in part of the following counterpart in English:

i) What are you planning to buy in the way of a car this year?

58 This discussion may carry over to the of of derived nominals such as:

(i) the removal of the evidence

which were argued to be relative clause structures by Collins (2006) and Kayne (2008a); cf. also Kayne (2015b). If they are, then the of in (i) is not the head of of the evidence. (If so, the head of of the evidence must be silent.) Note that in the papers mentioned, -al does not change the category of remove.

Whether a similar analysis of of can extend to cases like a large number of mistakes and/or to (nonstandard) He should of left (Kayne (1997)) remains to be worked out. (If of is akin to a relative pronoun, then it is not a "linker" in the sense of den Dikken (2006).)

59 Some English allows in despite of, suggesting that despite that might be "IN despite that", with a silent counterpart of in. Interesting questions arise here concerning the appearance vs. nonappearance of of, especially when one takes into account on board the ship. 
(95) without, within

with a component morpheme with- (cf. withhold) that pairs with either out or in. A fourth arguably involves the same $a$ - mentioned earlier in section 3 in the discussion of away as $a-+w a y$. This $a$ - is found in prepositions in cases like:

(96) atop the mountain

(97) astride the horse

If the preceding is on the right track, we could think of despite, behind, before, below, between, beyond, without, within, atop, and astride (and others like them) as "complex prepositions" associated with a constituent structure such as:

(98) [ a- top ] H the mountain

with $\mathrm{H}$ a silent head. Alternatively, this $\mathrm{H}$ (or perhaps $a$-itself) might occur in some or all of these cases in a structure more like:

(99) a- $\mathrm{H}$ [ top the mountain ]

with "top the mountain" a construct-state-like phrase. ${ }^{60}$

Whether a comparable constituent structure should be envisaged for the monomorphemic prepositions to, at, $b y$, and with is an open question. ${ }^{61}$ (If it should be, then Kayne's (1999; 2004) proposal that adpositions are merged outside VP will need to be revised. This open question includes that of English by in passives, as discussed by Collins (2005) in terms of Voice. ${ }^{62}$ )

The partial similarity between and and certain instances of with discussed in Kayne (1994, sect. 6.3), following Lakoff and Peters (1969), suggests the possibility that and might be an adposition and, therefore, fall under the preceding discussion. ${ }^{63}$ The existence in English of or else, as in:

(100) You'd better do it. Or else (they will).

is of interest, insofar as else is normally restricted to co-occurring with light nouns:

(101) something else, everybody else, noplace else

\footnotetext{
60 Cf. Longobardi (1996).

61 What we call case morphemes may (often) be a subtype of this latter class of adpositions; for recent relevant discussion, see Pesetsky (2014).

If applicative morphemes of the Bantu sort are subtypes of adpositions, then they probably fall into this latter class too.

62 It remains unclear how to integrate into Collins's perspective the passive $b y$-like morpheme, namely par, that occurs without a participle (but with an infinitive) in French causatives - cf. Kayne (1975, sect. 3.5) - in a way that recalls German and Dutch IPP sentences.

63 The implications for the restrictions on the (apparent) coordination of heads discussed in Kayne (1994, sect. 6.2) remain to be explored.
} 
or with the arguably (even) more complex where and one: ${ }^{64}$

(102) nowhere else, elsewhere, everyone else

The possibility, therefore, arises that or else involves at least as much extra material as a silent light noun, in which case $o r$ would very likely not be a projecting head with a sentential complement, even when it appears to be.

\section{Derivational suffixes}

The possible relative clause approach to derived nominals such as the removal of the evidence mentioned two sections ago does not require taking -al there to be a projecting head, especially if - $a l$ is itself what is relativized. It is plausible to think that as goes - al, so go nominal -ion,-ing, -ness, and -ity. (Verbal -en, -ify, -ize may be light verbs.) The morpheme -ish might be phrasal like more or less ${ }^{65}$ the morpheme -less as in shoeless might be phrasal in the way that without is. In other words, it might be that none of these suffixes are projecting heads in the way usually assumed. ${ }^{66}$

\section{Focus and Topic projections}

The Gungbe topic head discussed by Aboh (2004, sect. 8.1.3) and Rizzi (1997) might be a form of copula, thinking of (the imperfect analogy with) English cleft sentences. If it is, then the question of whether there are pronounced projecting heads related to topic projections becomes a(n open) question concerning the projecting ability of the copula. Whether other overt morphemes that appear to be focus or topic heads can be analyzed in this way remains to be seen. ${ }^{67}$

\section{Agreement morphemes}

Following in part Hale (1973) and related work, it seems likely that (at least) first and second person agreement morphemes of the sort widely found in European languages are (incorporated) pronouns. If such pronominal agreement morphemes therefore originate in or within an argument position, ${ }^{68}$ they clearly cannot be

64 On where and place, see Kayne (2007b).

${ }^{65}$ Cf. Duncan (2014).

66 Going back to Williams (1981).

${ }^{67}$ Kayne's (1994, Preface) analysis of Japanese - wa as a sentential head will have to be revised if there can be no such projecting heads. Where the $-t$ - of French subject clitic inversion fits in is not clear, though if projecting heads are necessarily silent, then Kayne and Pollock's $(2012 ; 2014)$ analysis of this $-t$ - will need to be revised.

${ }^{68}$ Cf. also Poletto (2000) on subject clitics of the North Italian type. Whether these subject clitics and pronominal agreement morphemes adjoin to a silent head or move to a Spec position is a separate question. Pronominal object clitics, too, are very likely to originate in or within argument position, as in Kayne (1975), in which case they cannot be pronounced sentential heads, contrary to Sportiche (1995) and Cuervo (2003). For an argument that at least some pronominal object clitics are actually phrasal, see Kayne (2008b). For an argument that object clitics of different persons move to different heights, see Săvescu-Ciucivara (2009). 
pronounced sentential heads in the way proposed by Pollock (1989) (although his arguments that they be separate from $\mathrm{T}$ will still hold). There could, though, be a corresponding sentential head that is silent, just as third person agreement often is. ${ }^{69}$

In some languages, in some cases, there is a verbal number (plural) agreement morpheme that is clearly distinct from person agreement. Almost certainly similar is Spanish plural $-n$ and Italian plural $-n(o) .{ }^{70}$ And arguably similar is the English $-s$ discussed by Paddock (1990) for (vernacular) Newfoundland English, which allows both of the following:

(103) It bees cold here. (generalization/ multiple instances)

(104) 'Tis cold here. (present time)

Paddock suggests more specifically that the $-s$ of (103) is the verbal counterpart of the plural $-s$ found with nouns. This suggestion of Paddock's would be compatible with having this $-s$ being a functional head in the sentential hierarchy (cf. also Shlonsky (1989)).

Alternatively, thinking in part of the discussion of tense morphemes in section 6 , it might be that the $-s$ of (103) is part of a larger phrase akin to many times:

(105) it be MANY TIME -s cold here

in which case this $-s$ would not be part of the sentential projection line. Whether this kind of analysis can be extended (with modification) to plural morphemes that appear to function only as agreement morphemes (i.e. that appear to be "uninterpretable") remains to be seen.

\section{Silent (Sentential) Heads I}

In many of the preceding sections, for example, in the discussion of complementizers, of sentence-final particles, of need, of aspect, of tense, of focus and topic, and of agreement morphemes, we have seen that familiar analyses with a pronounced head $\mathrm{H}$ (with complement $\mathrm{XP}$, as in $\{\mathrm{H}, \mathrm{XP}\}$ ) in the sentential projection line may give way to alternative analyses in which that pronounced head is no longer in the sentential projection line. Instead the corresponding head is silent.

Combining this with the observation that many of the sentential heads in Cinque's (1999) analysis of adverbs are silent, we arrive at the following conclusion: (106) Sentential heads are very often silent.

which seems to differ only in degree from the widespread view that sentential heads can sometimes be silent.

\footnotetext{
69 Cf. Harris (1969) on Spanish third person singular verbal agreement.

70 On French - ent, see Kayne and Pollock (2014). On cases in which Spanish - $n$ appears more than once, see Kayne (2010b).
} 
The conclusion stated in (106) seems weak, though, in at least two ways, if we interpret (106) as a hypothesis. First, (106) seems difficult to test, insofar as the term "very often" is not precise. Second, (106) seems unlikely to be derivable from any set of general principles. We might therefore consider strengthening (106) to: $:^{71}$

(107) All sentential heads are silent.

which looks to be more readily testable. A key question would then be, why would (107) hold, if correct?

A possible answer might lie within the question of what counts as atomic for Merge. We usually take morphemes to be atomic lexical items with respect to Merge. Yet morphemes are complex. Setting aside for the purposes of this paper the question of purely semantic features, morphemes have phonological features and formal features, which can be thought of as being bundled or assembled into a lexical item. ${ }^{72}$

Taking a cue, though, from recent discussions with Chris Collins and thinking of Agbayani and Ochi (2014) and references cited there, let me take such bundling or assembling to necessarily be an instance of Merge.

A problem seems to arise. If a lexical item is constructed by merging a (structured) set of phonological features/segments with a formal (syntactic) feature (or perhaps features), then a lexical item is not atomic and so cannot, strictly speaking, be a head H. Put another way, we can produce a pronounced lexical item via Merge but only at the cost of having that lexical item not be a true head. This apparent problem may provide the beginning of an account of (106)/(107), as follows.

A lexical item/morpheme associated with phonological features and at least one formal feature cannot be simplex. Therefore, it cannot be a (sentential) head, as noted. Instead, we have the following partial derivation for what we think of as a lexical item LI (with phonological features) that is supposed to merge with a phrase XP. The phonological features (PF) and formal features (FF) associated with LI merge with each other: ${ }^{73}$

71 The "doubly-filled Comp filter" tradition had already noticed that there are fewer pronounced heads than might be expected; cf. especially Starke (2004). For another view with some similarities to the one being proposed here, see Borer (2013).

The approach to be developed here will have certain points in common with Distributed Morphology (cf. Halle and Marantz (1993)), without adopting "late insertion", either in their sense or in the sense of nanosyntax (v. Starke (2009)). Informally put, I will end up having phonological and formal features "distributed in space" (i.e. in distinct positions) rather than "distributed in time", as in DM.

72 Cf. Chomsky (2001, 10), going back in part to Chomsky's (1995, sect. 4.4.4) "move feature" idea.

73 A variant of this idea (cf. Agbayani and Ochi (2014)) would be to have the formal feature(s) FF(LI) first merging with $\mathrm{XP}$, yielding $\{\mathrm{FF}(\mathrm{LI}), \mathrm{XP}\}$, followed by merging the phonological features $\mathrm{PF}(\mathrm{LI})$, yielding:

i) $\{\{\mathrm{PF}(\mathrm{LI}),\{\mathrm{FF}(\mathrm{LI}), \mathrm{XP}\}\}$ with $\mathrm{FF}(\mathrm{LI})$ again being the head/label of the entire syntactic object, so that all heads would be silent, as in the text formulation. 
The resulting syntactic object is then merged with XP, yielding:

(109) $\{\{\mathrm{PF}(\mathrm{LI}), \mathrm{FF}(\mathrm{LI})\}, \mathrm{XP}\}$

Thinking of Chomsky $(2013,43)$ and his discussion of labeling and minimal search, it is plausible, especially if $\mathrm{PF}(\mathrm{LI})$ is itself complex ${ }^{74}$ and if $\mathrm{FF}(\mathrm{LI})$ is a single feature, to take the head of the new syntactic object given in (109) to be $\mathrm{FF}(\mathrm{LI})$, which is by definition silent. (106)/(107) then follows.

Although (106)/(107) is stated for sentential heads, the point is of more general import. There is no reason to think that the type of derivation indicated in $(108) /(109)$ should be restricted to heads in the sentential projection line. The Merge sequence indicated in (108)(109) will consequently hold for any lexical item associated with phonological features that is merged with an XP. If so, then we appear to have, as a generalization of (106)/(107) (thinking in part of the earlier discussions of determiners, particles and adpositions):

(110) All or most heads are silent.

which is in need of clarification.

\section{Silent (Sentential) Heads II}

(110) is not sufficient. In the earlier sections on sentential elements such as complementizers, sentence-final particles, need, aspect, tense, focus and topic, and agreement morphemes, as well as in the sections on determiners, particles, and adpositions, the claim was made that what is usually taken to be the head of a certain phrase is not actually the head of that phrase, which should rather taken to be silent. The notion of "silent" used in those sections is stronger, though, than what is stated in (110).

\footnotetext{
74 It would also suffice if the labeling algorithm ignored phonological features.

It may be that $\mathrm{PF}(\mathrm{LI})$ is always complex, even if the LI in question is monosegmental. This would be so if phonological segments are built up from phonological features by Merge and if phonological segments cannot be monofeatural.

If phonological features are brought together by Merge and if it holds with complete generality that the output of Merge is associated in one way or another with linear/temporal order (cf. especially Kayne (2011)), then the expectation arises that phonological features within a segment must always be (totally) linearly/temporally ordered. (Such ordering is already suggested for particular cases by terms like "prenasalized stop" (cf. Maddieson (1989)) or "prestopped nasal" (cf. Turpin et al. (2014) and Round (2014)); it would presumably impose boundary conditions on the phonetics, without requiring the phonetics to display such ordering directly.)

If $\mathrm{PF}(\mathrm{LI})$ is generated by Merge and is subject to being externally merged with $\mathrm{FF}(\mathrm{LI})$, then we might expect $\mathrm{PF}(\mathrm{LI})$ to also be subject to internal Merge (cf. in part Chomsky (1995, sect. $4.4 .4 ; 2013,46)$ ), which could be taken to underlie, from the perspective of the copy theory of movement (cf. Chomsky $(2000,114)$ ), the existence of morphophonological/syntactic reduplication - cf. Marantz (1982), Travis (2003), and Frampton (2009). ((Partial) reduplication might involve remnant movement.)
} 
Consider, for example, tense. Familiar tense morphemes were suggested in section 6 to be demonstrative morphemes occurring as subparts of phrases akin to "at that time", with the tense morpheme corresponding to that. This is compatible with (110), but does not follow from it, since (110) would also be compatible with:

(111) $\{\{\mathrm{PF}(\mathrm{T}), \mathrm{FF}(\mathrm{T})\}, \mathrm{XP}\}$

with silent $\mathrm{FF}(\mathrm{T})$ the head, $\mathrm{PF}(\mathrm{T})$ the set of phonological features associated with the tense morpheme (e.g. -ed), and XP the phrase that best corresponds to the complement of T, say AspP. Consequently, if the analysis suggested in section 6 is on the right track and superior to (111), something further must be at issue.

A key difference between (111) and the analysis of section 6 lies in the absence in (111) of any counterpart to the silent noun TIME seen also in cases like:

(112) Have you been waiting long?

(113) Have you been waiting a long time?

It is virtually certain that (112) contains silent TIME (and perhaps a silent indefinite article). ${ }^{75}$ Section 6 took the position that ordinary tense morphemes are like long in (112) in needing to be accompanied by silent TIME. The next question is why TIME is needed both in (112) and with tense morphemes.

Kayne (2005a, Appendix) had proposed: ${ }^{76}$

(114) UG imposes a maximum of one interpretable syntactic feature per lexical item.

Setting aside the wording of (114), as well as for now the question of uninterpretable features, ${ }^{77}$ the intuition that (114) was intended to express is that lexical items are limited to making a minimal contribution to interpretation.

This is intended to mean, for example, that if long in (112) contributes an interpretation corresponding to some notion of magnitude, it cannot by itself also contribute the notion of "time". For (112) to be interpreted as involving time, (112) must necessarily contain the (silent) noun TIME, parallel to overt time in (113).

In parallel fashion, a tense morpheme such as English -ed cannot simultaneously contribute "time" and "in the past" to the interpretation; on the assumption that it contributes something like "in the past", it must be accompanied by silent TIME. For this reason, -ed cannot simply match $\{\mathrm{PF}(\mathrm{T})$,

75 Languages differ here (for reasons to be elucidated). French would have to have longtemps ("long time") with overt temps.

76 This proposal has a point in common with the claim made in Kayne $(1994 ; 2011)$ that heads can be associated with at most one Spec. Cf. also Cinque and Rizzi (2010).

77 If Kayne (1994; 2011) is correct in excluding multiple specifiers, uninterpretable features will almost certainly fall under the present discussion. 
$\mathrm{FF}(\mathrm{T})\}$ in (111), with XP equal to AspP. (If -ed is (part of) a demonstrative, as argued, then it will appear as $\{\mathrm{PF}(\mathrm{T}), \mathrm{FF}(\mathrm{T})\}$ in some $\{\{\mathrm{PF}(\mathrm{T}), \mathrm{FF}(\mathrm{T})\}, \mathrm{XP}\}$, but the XP there will be equal to NP or some similar phrase that demonstratives co-occur closely with.)

Akin to tense morphemes, from this perspective, are sentence-final particles, which are arguably associated with too complex an interpretation for them (more exactly, for their FF, if the discussion of (109) is on the right track) to be able to stand alone as a sentential head; rather, further silent elements of one sort or another must be present. Aspectual morphemes are presumably also akin to tense morphemes in this regard. Leu (2014) has taken a similar position for most determiners, as discussed in section 8; they are never simple lexical items that are associated with no silent elements. As suggested in section 3, particles like English away are not simple lexical items but are rather bimorphemic; whether a monomorphemic particle unaccompanied by any silent element is possible is an open question.

\section{Silent (Sentential) Heads III}

The discussion of (109) concluded that a formal feature FF, rather than a whole lexical item with its phonology, is the head/label of a phrase. In this technical sense, (107) is true (see also note 66). Yet (109) readily allows a lexical item to look like a pronounced head to the extent that $\mathrm{PF}(\mathrm{LI})$ is present and a sister to $\mathrm{FF}(\mathrm{LI})$.

Yet, the earlier sections on sentence-final particles, tense, aspect, etc. attempted to show that even that appearance is misleading, in the sense that the following (modeled on (109), with XP (say, AspP) a phrase in the sentential projection line) is not the right way to think about a tense morpheme like English -ed:

$$
\{\{\mathrm{PF}(\mathrm{T}=-e d), \mathrm{FF}(\mathrm{T})\}, \mathrm{AspP}\}
$$

Instead, - $e d$ must be taken to be subpart of a larger demonstrative phrase that (115) does not accommodate.

The section preceding this one suggested that (115) could in fact be excluded by recourse to (114) and that that effect of (114) might well extend beyond tense to sentence-final particles, aspectual morphemes, determiners, particles like up, etc., forcing them all out of the main projection line and into phrases (containing silent elements) whose existence we might not have been aware of such as the demonstrative phrase in the case of tense.

The applicability of (114) to (109), which is repeated here:

$$
\text { (116) }\{\{\mathrm{PF}(\mathrm{LI}), \mathrm{FF}(\mathrm{LI})\}, \mathrm{XP}\}
$$

is, however, limited to cases in which LI would have had to be too complex in interpretation. (114) would allow any instance of (116) in which LI is either uninterpretable or makes an appropriately minimal contribution to interpretation. 
In such cases, the LI in question would give the appearance of being a (sentential) head. A good candidate for such an LI would be a complementizer, especially from Rizzi's (1997) split-CP perspective.

In other words, if (114) were the only principle imposing limits on (116), we should expect to find many such instances involving a minimally interpretable (or uninterpretable) LI in the sentential projection line. But it is not clear that we do (if the empirical thrust of this paper leans in the right direction). If we do not find such instances, then (116) must be being suppressed, (at least) in the sentential projection line, by more than just (114).

A possible proposal would be the following. This proposal will be more transparent if we use the variant of (116) given in note 73 , which is: ${ }^{78}$

(117) $\{\mathrm{PF}(\mathrm{LI}),\{\mathrm{FF}(\mathrm{LI}), \mathrm{XP}\}\}$

In (117), $\mathrm{PF}(\mathrm{LI})$ is in a specifier-like position with respect to the head/label FF(LI). Assume, with Kayne (1994) or (in a different way) Kayne (2011), that multiple specifiers are prohibited. Then any FF(LI) head associated with a PF(LI) will be prohibited from having another LI or a phrase as (second) specifier.

Put another way, a pronounced LI will be unable to have (the equivalent of) a specifier. Consequently, if some FF needs another full LI or phrase as specifier, that FF will of necessity lack an associated PF of its own, that is, it will have to be silent. If all FFs in the sentential projection line need such "filled Specs", then all the heads/ labels in that projection line will have to be silent. (In effect, pronounced LIs will be restricted to occupying positions in which they would not need such a "filled Spec".)

\section{Conclusion}

On the basis of considerations involving complementizers, sentence-final particles, need, aspect, tense, focus and topic, agreement morphemes, determiners, particles, and adpositions, it appears that many more heads in the sentential projection line (and elsewhere) are silent than is usually thought. This reflects in part the fact that all projecting heads are technically silent (since they are just formal features) ${ }^{79}$ and in part the fact that the presence of phonological features precludes the presence of a(n other) specifier.

\footnotetext{
${ }^{78}$ Both variants will have the initial step of a derivation able to merge PF(LI) with FF(LI), with the latter counting as head/label, perhaps because PF(LI) is always complex - see note 74 . It may be that little $n$ (cf. Marantz (1997)) is unnecessary from the present perspective; nor would Chomsky's $(2013,47)$ prohibition against roots as labels be necessary.

In having $\mathrm{PF}(\mathrm{LI})$ subject to syntactic computation, the present proposal is not in the spirit of the "late insertion" aspect of DM (Halle and Marantz (1993)), nor with the phrasal spellout aspect of nanosyntax (Starke (2009)).

79 This will account for the doubly-filled Comp filter and its descendants; for a different approach, see Starke (2004).
} 


\section{Acknowledgments}

Earlier versions of this paper were presented at the University of Geneva in June 2012, at the Workshop on Complement(ation), University of Rome 3 in April 2013, at the Workshop on Portuguese Syntax, University of Venice in May, 2013, at Towards a Theory of Syntactic Variation, Bizkaia Aretoa, Bilbao (University of the Basque Country UPV/EHU) and at EdiSyn 2013, Konstanz in June 2013, at NYU in October, 2013, at MIT in April 2014, at GLOW in Asia X, National Tsing Hua University, Taiwan in May, 2014, and at GoetheUniversität, Frankfurt am Main in June, 2014. I am grateful for useful comments and questions to all those audiences, as well as to the anonymous reviewers of an earlier draft of this paper.

\section{References}

Aboh, Enoch Oladé. 2004. The morphosyntax of complement-head sequences. Clause structure and word order patterns in Kwa. New York: Oxford University Press.

Agbayani, Brian \& Masao Ochi. 2014. The split lexical Insertion hypothesis. Paper presented at the 40th Annual Conference of the Berkeley Linguistic Society, UC Berkeley, February.

Algeo, John. 2006. British or American English? A handbook of word and grammar patterns. Cambridge: Cambridge University Press.

Antonov, Anton \& Guillaume Jacques. 2014. Transitive need does not imply transitive have: Response to Harves and Kayne 2012. Linguistic Inquiry 45(1). 147-158.

Baker, Mark. 1985. The mirror principle and morphosyntactic explanation. Linguistic Inquiry 16(3). 373-415.

Baker, Mark C. 1988. Incorporation: A theory of grammatical function changing. Chicago: The University of Chicago Press.

Bolinger, Dwight. 1971. A further note on the nominal in the progressive. Linguistic Inquiry 2(4). 584-586.

Borer, Hagit. 2013. Heads and segments. Paper presented at the Workshop "Toward a Theory of Syntactic Variation", Bilbao, 5-7 June.

Bresnan, Joan W. 1972. Theory of complementation in English syntax, Cambridge, MA: Massachusetts Institute of Technology dissertation.

Cattaneo, Anderea. 2009. It is all about clitics: The case of a Northern Italian dialect like Bellinzonese. New York, NY: New York University dissertation.

Charnavel, Isabelle. 2011. On French un même and antispecificity. In Ingo Reich, Eva Horch \& Dennis Pauly. S (eds.), Proceedings of Sinn \& Bedeutung 15. 133-147. Saarbrücken: Saarland University Press .

Chomsky, Noam. 1995. The minimalist program. Cambridge, MA: The MIT Press.

Chomsky, Noam. 2000. Minimalist inquiries: The framework. In Roger Martin, David Michaels, Juan Uriagereka \& Samuel Jay Keyser (eds.), Step by step: Essays in minimalist syntax in honor of Howard Lasnik. 89-155. Cambridge, M.A: The MIT Press.

Chomsky, Noam. 2001. Derivation by phase. In Michael J. Kenstowicz (ed.), Ken 
Hale. A Life in language. 1-52. Cambridge, MA: The MIT Press.

Chomsky, Noam. 2013. Problems of projection. Lingua 130. 33-49.

Cinque, Guglielmo. 1999. Adverbs and functional heads. A cross-linguistic perspective.

New York: Oxford University Press.

Cinque, Guglielmo. 2004. 'Restructuring' and functional structure. In Adriana Belletti (ed.), (The Cartography of Syntactic Structures 3; Oxford Studies in Comparative Syntax), 132-191. New York: Oxford University Press (reprinted in Cinque (2006)).

Cinque, Guglielmo. 2006. Restructuring and functional heads. (The Cartography of Syntactic Structures 4; Oxford Studies in Comparative Syntax). New York: Oxford University Press.

Cinque, Guglielmo. 2010. The syntax of adjectives: A comparative study (Linguistic Inquiry Monographs 57). Cambridge, MA: The MIT Press.

Cinque, Guglielmo \& Luigi Rizzi. 2010. The cartography of syntactic structures. In Bernd Heine \& Heiko Narrog (eds.), The Oxford handbook of linguistic analysis. 51-65. Oxford: Oxford University Press.

Collins, Chris. 2005. A smuggling approach to the passive in English. Syntax 8. 81-120. Collins, Chris. 2006. A note on derivational morphology. Ms., New York University. Collins, Chris. 2008. Home sweet home. NYU Working Papers in Linguistics 1. 1-34. Coon, Jessica. 2010. Complementation in Chol (Mayan): A theory of split ergativity, Cambridge, MA: Massachusetts Institute of Technology dissertation.

Cuervo, Maria Cristina. 2003. Datives at large. Cambridge, MA: Massachusetts Institute of Technology dissertation.

Den Dikken, Marcel. 1995. Particles: On the syntax of verb-particle, triadic, and causative constructions. New York: Oxford University Press.

Den Dikken, Marcel. 2006. Relators and linkers. The syntax of predication, predicate inversion, and copulas. Cambridge, MA: The MIT Press.

Downing, Bruce T. 1978. Some universals of relative clause structure. In Joseph Harold Greenberg (ed.), Universals of Human Language 4: Syntax. 375-418. Stanford: Stanford University Press.

Duncan, Daniel. 2014. Formalizing the novel-ish Ish-construction in English. Ms., New York University.

Etxepare, Ricardo. 2010. From hearsay evidentiality to samesaying relations. Lingua 120. 604-627.

Frampton, John. 2009. Distributed reduplication. Cambridge, MA: The MIT Press.

Ghomeshi, Jila. 1996. Projection and inflection: A study of Persian phrase structure. Toronto: University of Toronto dissertation.

Ghomeshi, Jila. 2001. Control and thematic agreement. Canadian Journal of Linguistics 46. 9-40.

Haddican, Bill, Anders Holmberg, Hidekazu Tanaka \& George Tsoulas. 2014. Interrogative slifting in English. Lingua 138. 86-106.

Hale, Kenneth L. 1973. Person marking in Walbiri. In Stephen R. Anderson \& Paul Kiparsky (eds.), A festschrift for Morris Halle. 308-344. New York: Holt, Rinehart and Winston. 
Hale, Kenneth \& Samuel Jay Keyser. 1993. On argument structure and the lexical expression of syntactic relations. In Kenneth Hale \& Samuel J. Keyser (eds.) The View from building 20. Essays in linguistics in honor of Sylvain Bromberger (Current Studies in Linguistics Series 24), 53-109. Cambridge, MA: The MIT Press.

Hale, Kenneth \& Samuel Jay Keyser. 2002. Prolegomenon to a theory of argument structure. Cambridge, MA: The MIT Press.

Halle, Morris \& Alec Marantz. 1993. Distributed morphology and the pieces of Inflection. In Kenneth Hale \& Samuel Jay Keyser (eds.), The View from building 20. Essays in linguistics in honor of Sylvain Bromberger (Current Studies in Linguistics Series 24), 111-176. Cambridge, MA: The MIT Press.

Halpert, Claire \& Michael Diercks. 2013. No need for "have" (for "need"): A reply to Harves and Kayne (2012). Ms., University of Minnesota and Pomona College.

Harris, James W. 1969. Spanish phonology. Cambridge, MA: The MIT Press.

Harves, Stephanie \& Richard S. Kayne. 2012. Having need and needing have. Linguistic Inquiry 43. 120-132.

Jayaseelan, Karattuparambil A. 2008. Bare phrase structure and specifier-less syntax. Biolinguistics 2. 87-106.

Jayaseelan, Karattuparambil A. 2010. Stacking, stranding, and pied piping: A proposal about word order. Syntax 13. 298-330.

Julien, Marit. 2002. Syntactic heads and word formation. New York: Oxford University Press.

Katz, Jerold J. \& Paul M. Postal. 1964. An integrated theory of linguistic descriptions. Cambridge, MA: The MIT Press.

Kayne, Richard S.1975. French syntax. The transformational cycle. Cambridge, MA: The MIT Press.

Kayne, Richard S. 1981a. On certain differences between French and English. Linguistic Inquiry 12. 349-371 (reprinted in Kayne (1984)).

Kayne, Richard S. 1981b. Two notes on the NIC. In Adriana Belletti, Luciana Brandi \& Luigi Rizzi (eds.), Theory of markedness in generative grammar. Proceedings of the 1979 GLOW Conference. 317-346. Pisa: Scuola Normale Superiore (reprinted in Kayne (1984)).

Kayne, Richard S. 1984. Connectedness and binary branching. Dordrecht: Foris Publications.

Kayne, Richard S. 1989. Null subjects and clitic climbing. In Osvaldo Jaeggli and Kenneth Safir (eds.), The null subject parameter (Studies in Natural Language and Linguistic Theory), 239-261. Dordrecht: Reidel (reprinted in Kayne (2000)).

Kayne, Richard S. 1991. Romance clitics, verb movement and PRO. Linguistic Inquiry 22. 647-686 (reprinted in Kayne (2000)).

Kayne, Richard S. 1994. The antisymmetry of syntax. Cambridge, MA: The MIT Press.

Kayne, Richard S. 1997. The English complementizer of. Journal of Comparative Germanic Linguistics 1. 43-54. 
Kayne, Richard S. 1999. Prepositional complementizers as attractors. Probus 11. 3973.

Kayne, Richard S. 2000. Parameters and universals. New York: Oxford University Press.

Kayne, Richard S. 2003. Silent years, silent hours. In Lars-Olof Delsing, Gunlög Josefsson, Halldor Armann Sigurðsson \& Cecilia Falk (eds.), Grammar in focus: Festschrift for Christer Platzack. 18 November 2003. 2. 209-226. Lund: Wallin and Dalholm (reprinted in Kayne (2005b)).

Kayne, Richard S. 2004. Prepositions as probes. In Adriana Belletti (ed.), Structures and beyond (The Cartography of Syntactic Structures 3; Oxford Studies in Comparative Syntax), 192-212. New York: Oxford University Press.

Kayne, Richard S. 2005a. On the Syntax of Quantity in English. In Kayne (2005b).

Kayne, Richard S. 2005b. Movement and silence. New York: Oxford University Press.

Kayne, Richard S. 2007a. Some English (and Romance) auxiliaries. (Handout of) paper presented at XVII Colloquium on Generative Grammar, Universitat de Girona, 13-15 June.

Kayne, Richard S. 2007b. A short note on where vs. place. In Roberta Maschi, Nicoletta Penello \& Piera Rizzolatti (eds.), Miscellanea di Studi Linguistici offerti a Laura Vanelli da amici e allievi padovani. 245-257. Udine: Forum (reprinted in Kayne (2010c)).

Kayne, Richard S. 2008a. Antisymmetry and the lexicon. Linguistic Variation Yearbook 8. 1-31 (also in A.M. di Sciullo and C. Boeckx (eds.) The biolinguistic enterprise: New perspectives on the evolution and nature of the human language faculty. 329-353. London: Oxford University Press (2011)) (reprinted in Kayne (2010c)).

Kayne, Richard S. 2008b. Expletives, datives, and the tension between morphology and syntax. In Theresa Biberauer (ed.), The limits of syntactic variation. 175-217. Amsterdam: John Benjamins (reprinted in Kayne (2010c)).

Kayne, Richard S. 2010a. Why isn't this a complementizer? In Kayne (2010c).

Kayne, Richard S. 2010b. Toward a syntactic reinterpretation of Harris and Halle (2005). In Reineke Bok-Bennema, Brigitte Kampers-Manhe \& Bart Hollebrandse (eds.), Romance languages and linguistic theory 2008, selected papers from "Going Romance" Groningen 2008. 145-170. Amsterdam: John Benjamins.

Kayne, Richard S. 2010c. Comparisons and contrasts. New York: Oxford University Press.

Kayne, Richard S. 2011. Why are there no directionality parameters? In M. Byram Washburn, K. McKinney- Bock, E. Varis, Ann Sawyer and Barbara Tomaszewicz (eds.) Proceedings of the 28th West Coast Conference on Formal Linguistics, 1-23. Somerville, MA: Cascadilla Proceedings Project (also in 2013 Studies in Chinese Linguistics 34, 3-37).

Kayne, Richard S. 2014. Once and Twice. In Carla Contemori \& Lena Dal Pozzo (eds.), Inquiries into linguistic theory and language acquisition. Papers offered to Adriana Belletti. 114-129. Siena: CISCL Press (also in Studies in Chinese Linguistics 36(1), 1-20). 
Kayne, Richard S. 2015a. English one and ones as complex determiners. Ms., New York University.

Kayne, Richard S. 2015b. Antisymmetry and morphology. Prefixes and suffixes. Paper presented at Roots IV, New York University.

Kayne, Richard S. \& Jean-Yves Pollock. 2012. Toward an analysis of French hypercomplex inversion. In Laura Brugè, Anna Cardinaletti, Giuliana Giusti, Nicola Munaro \& Cecilia Poletto (eds.), Functional heads (Cartography of Syntactic Structures 7; Oxford Studies in Comparative Syntax), 150-167. New York: Oxford University Press (also in Kayne (2010)).

Kayne, Richard S. \& Jean-Yves Pollock. 2014. Locality and agreement in French hyper-complex inversion. In Enoch Oladé Aboh, Maria Teresa Guasti \& Ian Gareth Roberts(eds.), Locality. 32-57. New York: Oxford University Press.

Keenan, Edward L. 1985. Relative clauses. In Timothy Shopen (ed.), Language typology and syntactic description. Volume II. Complex constructions.141-170. Cambridge: Cambridge University Press.

Koopman, Hilda \& Dominique Sportiche. 1989. Pronouns, logical variables and logophoricity in Abe. Linguistic Inquiry 20. 555-588.

Koopman, Hilda \& Anna Szabolcsi. 2000. Verbal complexes. Cambridge, MA: The MIT Press.

Laka, Itziar. 2006. Deriving split ergativity in the progressive: The case of Basque. In Alans Johns, Diane Massam \& Juvenal Ndayiragije (eds.), Ergativity: Emerging issues. 173-196. Dordrecht: Springer.

Lakoff, George \& Stanley Peters. 1969. Phrasal conjunction and symmetric predicates. In David A. Reibel \& Sanford A. Schane (eds.), Modern Studies in English. 113142. New Jersey, Englewood Cliffs: Prentice-Hall.

Larson, Richard K. 1985. Bare-NP adverbs. Linguistic Inquiry 16. 595-621.

Law, Ann. 2002. Cantonese sentence-final particles and the CP domain. UCL Working Papers in Linguistics 14. 375-398.

Łazorczyk, Agnieszka Agata. 2010. Decomposing Slavic aspect: The role of aspectual morphology in Polish and other Slavic languages. Los Angeles, CA: University of Southern California dissertation.

Leu, Thomas. 2007. These here demonstratives. In Tatjana Scheffler, Joshua Tauberer, Aviad Eilam \& Laia Mayol (eds.), Proceedings of the 30th Annual Penn Linguistics Colloquium, Penn Working Papers in Linguistics 13(1). 141-154.

Leu, Thomas. 2008. What for internally. Syntax 11. 1-25.

Leu, Thomas. 2014. The architecture of determiners. New York: Oxford University Press.

Levinson, Lisa. 2011. Possessive with in Germanic: have and the role of P. Syntax 14. 355-393.

Liao, Wei-Wen Roger. 2015. Once upon an invisible time: On frequentative phrases in Chinese. Studies in Chinese Linguistics 36(1). 21-33.

Lin, Shih-Yueh Jeff. 2014. Questions, SFPs, and silence. Ms., New York University.

Lindner, Susan J. 1981. A lexico-semantic analysis of English verb particle constructions with out and up. San Diego: University of California, San Diego 
dissertation.

Longobardi, Giuseppe. 1994. Reference and proper names: A theory of N-movement in syntax and logical form. Linguistic Inquiry 25. 609-665.

Longobardi, Giuseppe. 1996. The syntax of N-raising: A minimalist theory. OTS Working Papers. Utrecht: Research Institute for Language and Speech, University of Utrecht.

Maddieson, Ian. 1989. Prenasalized stops and speech timing. Journal of the International Phonetic Association 19. 57-66.

Marantz, Alec. 1982. Re reduplication. Linguistic Inquiry 13. 435-482.

Marantz, Alec. 1997. No escape from syntax: Don't try morphological analysis in the privacy of your own lexicon. University of Pennsylvania Working Papers in Linguistics 4. 201-225.

Marušič, Franc \& Rok Žaucer. 2006. The "definite article” TA in colloquial Slovenian. In James Lavine, Steven Franks, Milla Tasseva-Kurktchieva \& Hana Filip (eds.) 189-204. Ann Arbor: Michigan Slavic Publications.

Matthews, Stephen \& Virginia Yip. 1994. Cantonese: A comprehensive grammar. Abingdon: Routledge.

Morin, Annick. 2009. On the Quebec French interrogative particle "tu”. In Enoch O. Aboh, Elisabeth van der Linden, Josep Quer \& Petra Sleeman (eds.), Romance languages and linguistic theory: Selected papers from "Going Romance" Amsterdam 2007. 201-222. Amsterdam: John Benjamins.

Nilsen, Øystein. 2003. Eliminating positions: The syntax and semantics of sentence modification. Utrecht: University of Utrecht dissertation.

Nurse, Derek. \& Henry Muzale. 1999. Tense and aspect in Great Lakes Bantu languages. In Jean-Marie Hombert \& Larry M. Hyman (eds.), Bantu Historical Linguistics. Theoretical and Empirical Perspectives. 517-544. Stanford, CA: CSLI Publications.

Ouhalla, Jamal. 2005. Clitic placement, grammaticalization, and reanalysis in Berber. In Guglielmo Cinque \& Richard Kayne (eds.), The Oxford handbook of comparative syntax. 607-638. New York: Oxford University Press.

Paddock, Harold. 1990. On explaining macrovariation in the Sibiliant and nasal suffixes of English. Folia Linguistica Historica 22, Issue Historica 9(1). 235 269.

Partee, Barbara Hall. 1973. Some structural analogies between tenses and pronouns in English. The Journal of Philosophy 70(18). 601-609.

Pereltsvaig, Asya. 2007. The universality of DP: A view from Russian. Studia Linguistica 61. 59-94.

Pesetsky, David. 1993. Topic... comment. Natural Language and Linguistic Theory 11. 557-558.

Pesetsky, David. 2014. Russian case morphology and the syntactic categories. Cambridge, MA: MIT Press.

Poletto, Cecilia. 2000. The higher functional field: Evidence from Northern Italian dialects. New York: Oxford University Press.

Pollock, Jean-Yves. 1989. Verb movement, universal grammar, and the structure of IP. 
Linguistic Inquiry 20. 365-424.

Pollock, Jean-Yves. 1998. On the syntax of subnominal clitics: Cliticization and ellipsis. Syntax 1. 300-330.

Rigau, Gemma. 1984. De com si no és conjunció i d'altres elements interrogatius. Estudis gramaticals: Working papers in linguistics 1. 249-278. Bellaterra: Universitat Autònoma de Barcelona.

Rimell, Laura. 2005. Tense and aspect projections in Niger-Congo languages. Ms., New York University.

Rizzi, Luigi. 1997. The fine structure of the left periphery. In L. Haegeman (ed.), Elements of grammar. Handbook of generative syntax. 281-337. Dordrecht: Kluwer.

Rosenbaum, Peter S. 1967. The grammar of English predicate complement constructions. Cambridge, MA: The MIT Press.

Ross, John R. 1970. On declarative sentences. In Roderick A. Jacobs \& Peter S. Rosenbaum (eds.), Readings in English transformational grammar. 222-272. Waltham, MA: Ginn.

Round, Erich. 2014. Prestopping of nasals and laterals is only partly parallel. In Rob Pensalfini, Myfany Turpin \& Diana Guillemin (eds.), Language description informed by theory. 81-95. Amsterdam: John Benjamins.

Sauerland, Uli. 2009. Decomposing question acts. Snippets 20. 62-63.

Sauerland, Uli \& Kazuko Yatsushiro. 2014. Remind-me presuppositions and speechact decomposition: Japanese "kke" and German "wieder" . Ms., ZAS, Berlin.

Săvescu-Ciucivara, Oana. 2009. A syntactic analysis of pronominal clitic clusters in Romance. The view from Romanian. New York: New York University dissertation.

Shlonsky, Ur. 1989. The hierarchical representation of subject verb agreement. Ms., University of Haifa.

Simpson, Andrew \& Zoe Wu. 2002a. IP-raising, tone sandhi and the creation of S-final particles: Evidence for cyclic spell-out. Journal of East Asian Linguistics 11. 67-99.

Simpson, Andrew \& Zoe Wu. 2002b. Understanding cyclic spell-out. In Mako Hirotani (ed.), Proceedings of North Eastern Linguistic Society (NELS) 32. 499518. Amherst: GLSA Publications.

Sportiche, Dominique. 1995. Clitic Constructions. In Laurie Zaring \& Johan Rooryck (eds.), Phrase structure and the lexicon. 213-276. Kluwer: Dordrecht.

Starke, Michal. 2004. On the inexistence of specifiers and the nature of heads. In Adriana Belletti (ed.), Structures and beyond (The Cartography of Syntactic Structures 3; Oxford Studies in Comparative Syntax), 252-268. New York: Oxford University Press.

Starke, Michal. 2009. Nanosyntax. A short primer to a new approach to language. Nordlyd 36(1). 1-6.

Tang, Sze-Wing. 2015. A generalized syntactic schema for utterance particles in Chinese. Lingua Sinica 1. 1-23.

Terzi, Arhonto. 2010. Locative prepositions and place. In Guglielmo Cinque \& Luigi Rizzi (eds.), Mapping spatial PPs (The Cartography of Syntactic Structures 6; Oxford 
Studies in Comparative Syntax), 196-224. New York: Oxford University Press.

Travis, Lisa DeMena. 2003. Reduplication feeding syntactic movement. In Sophie Burelle \& Stanca Somesfalean (ed.), Proceedings of Canadian Linguistics Association (CLA). 236-247. Montréal, QC: Université du Québec à Montréal.

Turpin, Myfany, Katherine Demuth \& April Ngampart Campbell. 2014. Phonological aspects of Arandic baby talk. In Rob Pensalfini, Myfany Turpin \& Diana Guillemin (eds.), Language description informed by theory. 49-80. Amsterdam: John Benjamins.

Vinet, Marie Thérèse. 2000. Feature representation and -tu (pas) in Quebec French. Studia Linguistica 54(3). 381-411.

Williams, Edwin. 1981. On the notions "lexically related" and "head of a word". Linguistic Inquiry 12. 245-274.

Address: Department of Linguistics, New York University, 10 Washington Place \#403, New York, NY 10003, USA

Email: $\quad$ richard.kayne@nyu.edu

Received: September 11, 2014

Accepted: September 11, 2014 


\title{
有關中心語的 “無聲說”
}

\author{
Richard S. Kayne \\ 紐約大學
}

\section{提要}

本文探討的對象包括標句詞、句末助詞、“need”、體、時、焦點與話題、一致關係 語素、限定詞、與動詞有關的助詞、介詞, 得出的結論是 : 在句子投射系列及其他 位置上, 無聲中心語的數目應該遠多於過去所理解。本文進而指出, 以上的情況都 說明一個事實, 那就是中心語都是無聲的成分。

\section{關鍵詞}

標句詞，句末助詞，無聲成分，時，特徵 